\title{
New isolates of ectomycorrhizal fungi and the growth of eucalypt
}

\author{
Luiz Afonso Borges de Souza ${ }^{(1)}$, Pedro Augusto Pinto Bonnassis(1), Germano Nunes Silva Filho ${ }^{(1)}$ \\ and Vetúria Lopes de Oliveira ${ }^{(1)}$
}

(1)Universidade Federal de Santa Catarina, Departamento de Microbiologia e Parasitologia, Campus Universitário da Trindade, Caixa Postal 476, CEP 88040-900 Florianópolis, SC, Brazil. E-mail: borges@ccb.ufsc.br, pedrobonna@ccb.ufsc.br, germano@ccb.ufsc.br, veturia@ccb.ufsc.br

\begin{abstract}
The objective of this work was to evaluate the efficiency of ectomycorrhizal isolates on root colonization, phosphorus uptake and growth of Eucalyptus dunnii seedlings. Inocula of ten ectomycorrhizal isolates of Chondrogaster angustisporus, Hysterangium gardneri, Pisolithus spp., and Scleroderma spp. were aseptically produced in a peat-vermiculite mixture supplemented with liquid culture medium. Plants grew in a similar substrate supplemented with macro- and micro-nutrients; treatments were randomly distributed in a greenhouse. After three months, seedlings inoculated with three isolates - UFSC-Sc68 (Scleroderma sp.), UFSC-Ch163 (Chondrogaster angustisporus), and UFSC-Pt188 (Pisolithus microcarpus) - had a phosphorus shoot content and a shoot dry matter higher or equivalent to those of noninoculated controls which had been fertilized with a 16-fold phosphorus amount. These isolates were selected for new studies for establishing inoculum production techniques, in order to be applied in reforestation programmes under nursery and field conditions.
\end{abstract}

Index terms: Chondrogaster, Pisolithus, Eucalyptus dunnii, efficiency, inoculation, plant growth.

\section{Novos isolados de fungos ectomicorrízicos e o crescimento de eucalipto}

\begin{abstract}
Resumo - O objetivo deste trabalho foi avaliar a eficiência de isolados fúngicos ectomicorrízicos na colonização radicular, na absorção de fósforo e no crescimento de mudas de Eucalyptus dunnii. Os inóculos de dez isolados de Chondrogaster angustisporus, Hysterangium gardneri, Pisolithus spp. e Scleroderma spp. foram produzidos em uma mistura turfa-vermiculita suplementada com meio de cultura líquido. As plantas foram cultivadas em substrato semelhante com macro e micronutrientes. Os tratamentos foram distribuídos em casa de vegetação em delineamento inteiramente casualizado. Após três meses, as plântulas com inoculação dos isolados - UFSC-Sc68 (Scleroderma sp.), UFSC-Ch163 (Chondrogaster angustisporus) e UFSC-Pt188 (Pisolithus microcarpus) - tiveram os maiores valores de matéria seca e de fósforo na parte aérea. Esses valores foram superiores ou equivalentes aos observados nas plantas sem inoculação, adubadas com 16 vezes mais fósforo. Esses isolados foram selecionados para futuros estudos, a fim de se estabelecerem técnicas de produção de inoculantes, para serem usados em programas de reflorestamento em condições de viveiros e campo.
\end{abstract}

Termos para indexação: Chondrogaster, Pisolithus, Eucalyptus dunnii, eficiência, inoculação, crescimento vegetal.

\section{Introduction}

The increasing need of forest products has created a worldwide deficit of timber that has to be met using strategies designed to promote a higher productivity. In addition, many Brazilian reforestation programmes have to deal with soil low fertility, which requires the application of very high amounts of fertilizers to maintain the productivity at the present levels. This practice contributes to high production costs and has deleterious environmental effects.

Eucalypt, the most employed plant in Brazil are fast growing trees with the ability to associate with ectomycorrhizal (ECM) fungi, forming mutual symbioses that improve plant growth. Ectomycorrhizas contribute to increase water and nutrient uptake, particularly those presenting low mobility in the soil, such as phosphorus (Glowa et al., 2003; Sawyer et al., 2003; Di Pietro et al., 2007). This increase in nutrient uptake is the result of a significant increase in the plant-soil interface due to the growth of the hyphae of the ectomycorrhizal fungus beyond the root zone and to the more intense branching of the colonized roots (Smith \& Read, 1997; Zeppa et al., 2005). Ectomycorrhizas can also augment hydraulic conductivity inside the plant and the resistance to drought and soil-borne pathogens, and can improve soil 
aggregation and structure (Tisdall et al., 1997; BogeatTriboulot et al., 2004; Mucha et al., 2006). Through these different mechanisms, ectomycorrhizas promote plant growth and productivity even in soils with low fertility or disturbed.

Mycorrhizas are a very important factor contributing to forest productivity. In the case of forest plantations, introduction of compatible and efficient ectomycorrhizal fungi is crucial to assure plant survival and growth. However, a range of fungal species form ectomycorrhizas, and they all differ in terms of the benefits to host plants, even between isolates of the same species (Mason et al., 2000; Souza et al., 2004; Chen et al., 2006b; Di Pietro et al., 2007). The exploitation of the ectomycorrhizal symbiosis to promote plant nutrition and growth requires compatible and efficient ECM isolates. Their pursuit is, therefore, a constant task when dealing with controlled mycorrhization programmes, considering the great diversity of hosts and environmental conditions, where they are expected to improve plant growth, and the fact that many isolates may loose their infectivity and efficiency after long-term cultivation.

In this context, new ectomycorrhizal isolates have to be obtained and maintained in culture collections, to allow studies on the fungus-host compatibility, and their efficiency in promoting plant growth before the isolates are employed in large-scale nursery systems (Oliveira et al., 1994; Souza et al., 2004; Chen et al., 2006b).

This study aimed to identify new efficient ectomycorrhizal isolates, from those in the Universidade Federal de Santa Catarina culture collection, which are able to promote root colonization, $\mathrm{P}$ uptake, and growth of Eucalyptus dunnii Maiden seedlings.

\section{Materials and Methods}

Ten isolates of ectomycorrhizal fungi were employed in this study. They were obtained from eucalypt plantations, and kept in the culture collection at the Laboratório de Ectomicorrizas, Departamento de Microbiologia e Parasitologia, Universidade Federal de Santa Catarina, Florianópolis, SC, Brazil.

Isolate SA9 is from Australia, where it was isolated from Eucalyptus calmaldulensis forests. All other isolates, except for the UFSC-Pt188, obtained from fruiting bodies harvested in Minas Gerais (Southeastern), were from Santa Catarina (Southern) Brazil. Isolates UFSC-Ch98 and UFSC-Ch163 belong to a newly identified species, Chondrogaster angustisporus Giachini, Castellano, Trappe \& V.L. Oliveira, described by Giachini et al. (2000). This species has also been recently found in eucalypt plantations in Spain (Alvarez \& Cerceda, 2005). Isolates UFSC-Pt116, UFSC-Pt132 and UFSC-Pt188 belong to the species Pisolithus microcarpus (Cooke \& Massee) G. Cunn. Isolates UFSC-Pt22 and UFSC-Pt145 are unidentified species of the genus Pisolithus. Isolate UFSC-Sc68 is a Scleroderma sp., and isolate SA9 belongs to the species Scleroderma flavidum Ellis \& Everth. Isolate UFSC-Hg93 belongs to the species Hysterangium gardneri E. Fischer.

Isolates from the culture collection grew on MMNagar medium (Marx, 1969) in Petri dishes, at $25 \pm 1^{\circ} \mathrm{C}$ for 30 days. Mycelium and medium plugs, $8 \mathrm{~mm}$ diameter, were removed aseptically from the edge of the colonies and placed on fresh MMN-agar medium to verify their viability and purity. After a three-day incubation period, viable plugs were transferred to liquid MMN: three plugs per $25 \mathrm{~mL}$ of medium in $250 \mathrm{~mL}-$ Erlenmeyer flasks. For each isolate, 12 flasks were prepared and incubated at $25 \pm 1^{\circ} \mathrm{C}$ for 20 days. The contents of 4 flasks $(100 \mathrm{~mL}$ in total $)$ were fragmented in a Warring blender $(3,600 \mathrm{rpm})$ for $5 \mathrm{~s}$, and used to inoculate $500 \mathrm{~mL}$ of sterilized peat-vermiculite $(1: 4, \mathrm{~V} / \mathrm{V})$ moistened with $200 \mathrm{~mL}$ of liquid MMN solution in $900 \mathrm{~mL}$-flasks. Three flasks were produced for each isolate, and incubated at $25 \pm 1^{\circ} \mathrm{C}$ for two months. For the control treatments, a noninoculated peatvermiculite-MMN solution mixture was produced and kept at the same incubation conditions as the inoculated flasks. Before application, inocula were tested for fungal viability and purity by placing two samples of $1 \mathrm{~g}$ from each flask on the surface of MMN-agar medium, in Petri dishes, and incubating at $25 \pm 1^{\circ} \mathrm{C}$ for two days.

Eucalyptus dunnii seeds were disinfected by immersion in ethanol $70 \%$ for $1 \mathrm{~min}$, washed in sterile distilled water, and germinated under constant agitation in a sterilized nutrient solution containing boric acid $(3 \mu \mathrm{M})$, glucose $\left(2 \mathrm{~g} \mathrm{~L}^{-1}\right)$ and calcium sulphate $(500 \mu \mathrm{M}), \mathrm{pH} 5.7$, for three days at room temperature (Chen et al., 2000).

Planting substrate was a mixture of peat and vermiculite (1:3, V/V), twice sterilized at $121^{\circ} \mathrm{C}$, for $60 \mathrm{~min}$. This substrate was fertilized with a nutrient solution containing (mg per plant): $\mathrm{K}, 16 ; \mathrm{Mn}, 0.15 ; \mathrm{Mg}, 3 ; \mathrm{Zn}, 0.0375$; $\mathrm{Cu}, 0.125$; Mo, 0.05; B, 0.05; and Fe, 0.375, the same 
amounts used by Alves et al. (2001). Ammonium nitrate was added every 15 days to provide $35 \mathrm{mg} \mathrm{N}$ per plant. Phosphorus as $\mathrm{Ca}\left(\mathrm{H}_{2} \mathrm{PO}_{4}\right)_{2} \cdot \mathrm{H}_{2} \mathrm{O}$ was added to the inoculated treatments at $0.5 \mathrm{mg}$ per plant. Three noninoculated control treatments were established using the following rates of $\mathrm{P}$ added per plant: no added $\mathrm{P}$ (NI 0 P), $0.5 \mathrm{mg}$ of P per plant (NI $0.5 \mathrm{P}$ ), and $8 \mathrm{mg}$ of $\mathrm{P}$ per plant (NI $8 \mathrm{P}$ ).

After sterilization and fertilization, the planting substrate was dried at $70^{\circ} \mathrm{C}$ for three days to eliminate excess moisture. Inoculation was performed immediately before sowing, by mixing one part of inoculated peat and vermiculite mixture with nine parts of planting substrate (Alves et al., 2001). Before use, the inoculated peat and vermiculite mixture was washed in sterile distilled water to eliminate residues of the culture medium.

The inoculated substrate was distributed in conical plastic pots $(60 \mathrm{~mL})$ and placed in a greenhouse on polystyrene trays. Each pot received 4-5 germinated seeds, placed $1 \mathrm{~cm}$ deep. Germinated seeds were covered with the substrate and watered with sterile distilled water. Two weeks latter, seedlings were thinned to one per pot.

Treatments were randomly distributed in the greenhouse. Noninoculated controls were prepared by adding to the planting substrate the same proportion of a fungus-free peat-vermiculite mixture as that employed for inoculated plants. There were five plants per treatment.
Plants remained for three months under greenhouse conditions. Temperatures during the experimental period varied from $18^{\circ} \mathrm{C}$ (night) to $30^{\circ} \mathrm{C}$ (day). They were harvested and analysed in terms of percentage of root colonization, plant height and shoot dry matter. Phosphorus content was determined by using the technique described by Tedesco et al. (1995). Results were submitted to variance analysis and averages were compared using Tukey test $(\mathrm{p} \leq 0.05)$.

Mycorrhizal colonization was observed under a dissecting microscope (10-30X) and measured according to Brundrett et al. (1996). Further morphological and anatomical details were obtained using cryo-microtomed sections $(10-30 \mu \mathrm{m})$ observed under optical microscopy.

\section{Results and Discussion}

Root colonization was higher in plants inoculated with Pisolithus isolates (Table 1), UFSC-Pt22, UFSC-Pt145, UFSC-Pt188 and UFSC-Pt116, which colonized 10 to $12 \%$ of the root systems. Isolates UFSC-Sc68 (Scleroderma sp.) and UFSC-Ch163 (Chondrogaster angustisporus) colonized 8 and 7\%, respectively.

Plants inoculated with isolates UFSC-Pt132 (Pisolithus microcarpus) and UFSC-Hg93 (Hysterangium gardneri) produced lower colonization rates at 4 and $3 \%$, respectively. No colonization by the isolates SA9 (Scleroderma flavidum) and UFSC-Ch98 (C. angustisporus) was detected. No colonization was observed on noninoculated controls (NI),

Table 1. Effect of the inoculation of Eucalyptus dunnii seedlings with ectomycorrhizal isolates on root colonization, plant dry matter and shoot phosphorus $(\mathrm{P})$ content after three months in greenhouse ${ }^{(1)}$.

\begin{tabular}{|c|c|c|c|c|c|}
\hline \multirow{2}{*}{$\begin{array}{l}\text { Inoculation } \\
\text { treatments }^{(2)}\end{array}$} & \multirow{2}{*}{$\begin{array}{c}\text { Root colonization } \\
(\%)\end{array}$} & \multicolumn{3}{|c|}{ Dry matter (g per plant) } & \multirow{2}{*}{$\begin{array}{l}\text { Shoot } \mathrm{P} \text { content } \\
\left(\mu \mathrm{g} \mathrm{pl}^{-1}\right)\end{array}$} \\
\hline & & Shoot & Roots & Total & \\
\hline$\overline{\text { NI } 0 \mathrm{P}}$ & $0 \mathrm{~d}$ & $0.93 \mathrm{e}$ & $0.28 \mathrm{~d}$ & $1.21 \mathrm{~g}$ & $60 \mathrm{~h}$ \\
\hline NI $0.5 \mathrm{P}$ & $0 \mathrm{~d}$ & $1.39 \mathrm{de}$ & $0.36 \mathrm{~cd}$ & $1.75 \mathrm{fgh}$ & $87 \mathrm{fgh}$ \\
\hline NI $8 \mathrm{P}$ & $0 \mathrm{~d}$ & $2.37 \mathrm{abc}$ & $0.57 \mathrm{abc}$ & $2.94 \mathrm{abcd}$ & $372 b$ \\
\hline UFSC-Ch98 & $0 \mathrm{~d}$ & $1.73 \mathrm{bcd}$ & $0.54 \mathrm{abc}$ & $2.27 \mathrm{cdef}$ & $80 \mathrm{gh}$ \\
\hline UFSC-Ch163 & $7 \mathrm{c}$ & $2.76 \mathrm{ab}$ & $0.66 \mathrm{a}$ & $3.42 \mathrm{ab}$ & $278 \mathrm{bcd}$ \\
\hline UFSC-Hg93 & $3 d$ & $1.41 \mathrm{de}$ & $0.40 \mathrm{~cd}$ & $1.81 \mathrm{efg}$ & $58 \mathrm{~h}$ \\
\hline UFSC-Pt22 & $12 \mathrm{a}$ & $2.07 \mathrm{bcd}$ & $0.60 \mathrm{abc}$ & $2.67 \mathrm{bcdef}$ & $256 \mathrm{cde}$ \\
\hline UFSC-Pt116 & $10 \mathrm{ab}$ & 2.29abcd & $0.53 \mathrm{abcd}$ & 2.82abcde & $193 \mathrm{def}$ \\
\hline UFSC-Pt132 & $4 \mathrm{~cd}$ & $2.66 \mathrm{ab}$ & $0.61 \mathrm{abc}$ & $3.24 \mathrm{abc}$ & $175 \mathrm{efg}$ \\
\hline UFSC-Pt145 & $12 \mathrm{a}$ & $2.02 \mathrm{bcd}$ & $0.54 \mathrm{abc}$ & $2.56 \mathrm{bcdef}$ & $213 \mathrm{def}$ \\
\hline UFSC-Pt188 & $11 \mathrm{ab}$ & $2.87 \mathrm{ab}$ & $0.67 \mathrm{a}$ & $3.54 \mathrm{ab}$ & $528 \mathrm{a}$ \\
\hline UFSC-Sc68 & $8 \mathrm{bc}$ & $3.08 \mathrm{a}$ & $0.67 \mathrm{a}$ & $3.75 \mathrm{a}$ & $346 b c$ \\
\hline SA9 & $0 \mathrm{~d}$ & $1.52 \mathrm{cde}$ & $0.45 \mathrm{bcd}$ & $1.97 \mathrm{defg}$ & $168 \mathrm{efg}$ \\
\hline
\end{tabular}

${ }^{(1)}$ Values are the averages of five replicates; those in the columns followed by equal letters are not significantly different, according to the Tukey test $(\mathrm{p} \leq 0.05)$. (2) NI 0 P: noninoculated control without P added; NI 0.5 P: noninoculated control with $0.5 \mathrm{mg}$ of P per plant; NI 8 P: noninoculated control with $8 \mathrm{mg}$ of $\mathrm{P}$ per plant. 
regardless the doses of $\mathrm{P}$ applied $(0 \mathrm{mg}, 0.5 \mathrm{mg}$ or $8 \mathrm{mg}$ P per plant).

Shoot dry matter (Table 1) was higher in plants inoculated with isolates UFSC-Sc68, UFSC-Pt188, UFSC-Ch163, UFSC-Pt132 or UFSC-Pt116, and these plants were significantly heavier than those inoculated with any of the other five isolates. They were also heavier than the noninoculated controls without P (NI 0 P), or with $0.5 \mathrm{mg} \mathrm{P}$ per plant (NI $0.5 \mathrm{P}$ ). Plants inoculated with these five efficient isolates produced as much dry matter as the noninoculated controls which had been fertilized with 16 times more P per plant (NI 8P).

Plants colonized by isolates USFC-Sc68, UFSC-Pt188 or UFSC-Ch163 had the most root dry matter (Table 1). They were significantly heavier than the noninoculated controls fertilized with $0.5 \mathrm{mg} \mathrm{P}(\mathrm{NI} 0.5 \mathrm{P}$ ) and those without $\mathrm{P}$ (NI $0 \mathrm{P}$ ). They were also heavier than the plants inoculated with isolate UFSC-Hg93. Plants of this latter treatment had the least root dry matter, though were not significantly less than the observed for control plants which had received no P (NI $0 \mathrm{P}$ ) or $0.5 \mathrm{mg} \mathrm{P}$ per plant (NI $0.5 \mathrm{P})$.

Total dry matter results were similar to those seen for root or shoot dry matter. Plants inoculated with isolates UFSC-Sc68, UFSC-Pt188, UFSC-Ch163, UFSC-Pt132 or UFSC-Pt116 were heavier than the noninoculated controls (NI $0 \mathrm{P}$ and NI $0.5 \mathrm{P}$ ). Plants inoculated with these isolates produced as much dry matter as the noninoculated controls, which received the most $\mathrm{P}$ per plant (NI $8 \mathrm{P}$ ).

Isolate UFSC-Pt188 promoted the highest shoot $\mathrm{P}$ content in plant tissues (528 $\mu$ g per plant) (Table 1$)$. Also isolates UFSC-Sc68 (346 $\mu \mathrm{g}$ per plant) and UFSC-Ch163 ( $278 \mu \mathrm{g}$ per plant) had significant effects on shoot $\mathrm{P}$ content, recovering 69.2 and $55.6 \%$ of the applied phosphorus. This is an important result, considering that it is only the content of $\mathrm{P}$ in the shoots.

Plants inoculated with isolates UFSC-Pt188, UFSC-Sc68 or UFSC-Ch163 had, respectively, 500, 300 and 220\% more $\mathrm{P}$ in their shoots, compared with noninoculated controls which had received the standard $\mathrm{P}$ dosage (NI 0.5 P). Plants inoculated with isolate UFSC-Pt22 had similar amounts of $\mathrm{P}$ in their shoots $(256 \mu \mathrm{g}$ per plant) as those inoculated with isolates UFSC-Sc68 or UFSC-Ch163.

Colonization ratios seen in this study were similar to those ratios for two isolates of the ECM fungus Descolea maculata in Eucalyptus diversicolor roots in a study reported by Bougher et al. (1990): 9.8 and $14.4 \%$. The Pisolithus isolate studied by these authors did not colonize the plants. In contrast, Alves et al. (2001) observed a higher colonization ratio (27 to $40 \%$ ) in E. dunnii roots by the isolate UFSC-Pt24 of Pisolithus sp., though the plants had dry matter values significantly smaller than those observed in this study. The differences between these results may be due to other factors than those related to the isolates themselves, for example, the techniques employed to evaluate root colonization, or the fact that Alves et al. (2001) used a controlled release fertilizer, whereas in this study the fertilizer was applied as a solution. Mason et al. (2000) observed colonization ratios ranging from 1.4 to $40 \%$, when they studied the effect of phosphorus concentration on mycorrhizal development and growth of $E$. globulus seedlings, inoculated with ten different ECM fungi under nursery conditions.

Considering the diversity of fungal species involved, it is also possible that the differences among isolates, in relation to root colonization, would have been greater if measured earlier or latter than the three-month growth period. However, periods of 3 to 4 months are considered, by many authors, as the most adequate to access ectomycorrhizal establishment in many forest plant species (Bougher et al., 1990; Alves et al., 2001; Zeppa et al., 2005; Chen et al., 2006a, 2006b). The results showed that even with low colonization ratios, isolates UFSC-Sc68, UFSC-Pt188 and UFSC-Ch163 were able to promote plant nutrition and growth. This fact indicates that these isolates have a significant mycorrhizal efficiency.

Although many authors believe that colonization ratios have a direct relationship with growth promoting effects (Garbaye, 1990; Thomson et al., 1994; Turjaman et al., 2005), in other instances there has been a poor correlation between these two factors (Souza et al., 2004). In the present study, it was observed that isolates which produced higher colonization levels were not necessarily those that promoted better plant growth. This was found with isolates UFSC-Pt22 and UFSC-Pt145, which showed the highest colonization ratios but were not able to promote a higher $\mathrm{P}$ uptake or a higher biomass production, compared to the other isolates studied.

Smith \& Read (1997) pointed out that the extraradical component of ectomycorrhizas is extremely important in exploring soil resources far beyond the zones of nutrient depletion. In the case of mat-forming fungi, this attribute may be more important than the number or the percentage of colonized roots. This fact could be implied in the differences among isolates, in plant growth promotion and $\mathrm{P}$ uptake. 
However, there are studies indicating that hyphal development in soil is not a good indicator of mycorrhizal efficiency (Thomson et al., 1994).

Differences among the isolates, in terms of root colonization, were remarkable, even those observed between isolates of the same species. Chondrogaster angustisporus isolates UFSC-Ch98 and UFSC-Ch163 had been collected from E. dunnii plantations in Santa Catarina State, but only UFSC-Ch163 colonized roots in this study. The inoculum of both isolates was viable at the time of plant inoculation. Differences among isolates of the same species of ECM fungi, in colonizing and promoting beneficial effects on plant hosts, have been reported elsewhere (Oliveira et al., 1994; Chen et al., 2006b). The differences in efficiency, which occurred between isolates of the same fungal species, indicate the significance of screening and selecting ectomycorrhizal fungi for a controlled mycorrhization programme.

Isolate SA9 did not colonize seedlings of $E$. dunnii in this study, and is possibly incompatible with E. dunnii, coming as it did from an E. calmadulensis area in Australia. Differences in terms of host range, among ectomycorrhizal isolates of the same species or genus, from different geographic regions, have been already observed (Oliveira et al., 1994) and are now being studied through molecular tools (Martin et al., 2002). However, the differences between isolates UFSC-Ch98 and UFSC-Ch163, discussed previously, cannot be explained on the basis of their provenance, as both were obtained from E. dunnii and belong to the same species. This suggests that some factors, related to the experimental conditions or to the physiology of the isolates, could be implicated in the results. This also points to the need for selection studies, in order to identify efficient isolates. Selection studies should be a prerequisite, when considering using mycorrhizas in forestry. They should also be carried out in many different conditions.

Plants inoculated with isolate UFSC-Pt188 had P contents higher than $0.5 \mathrm{mg}$, which indicates that they were able to recover all $\mathrm{P}$ applied ( $0.5 \mathrm{mg} \mathrm{P}$ per plant), as well as the $\mathrm{P}$ fraction in the substrate, probably from a component of the peat. This latter assumption is corroborated by evidences showing that some ectomycorrhizal fungi are able to utilize organic sources of P from soil organic matter (Smith \& Read, 1997; Sawyer et al., 2003). Others studies have shown that ectomycorrhizal fungi may produce organic acids and phosphatases, and that these may help them to solubilize inorganic and organic insoluble forms of $\mathrm{P}$ (Wallander, 2000; Landeweert et al., 2001; Hofland et al., 2004). Isolate UFSC-Pt188, a P. microcarpus isolate, was the most efficient of the isolates tested in improving $\mathrm{P}$ uptake. Plants inoculated with this isolate had shoot $\mathrm{P}$ contents significantly greater than the plants used in all others treatments, even those of the noninoculated controls that had received the highest dose of $\mathrm{P}$ (NI $8 \mathrm{P}$ ).

Bougher et al. (1990) observed an increase in $\mathrm{P}$ uptake by plants of $E$. diversicolor inoculated with different ECM isolates, when compared with noninoculated controls. However, in the present study, the application of only $0.5 \mathrm{mg}$ P per plant was enough to promote the similar growth increases, as those obtained by these authors with $8-20$ fold $\mathrm{P}$ doses. Though Alves et al. (2001) obtained higher levels of P uptake in $E$. dunnii, using another Pisolithus sp. isolate, they had applied a much higher $\mathrm{P}$ fertilization regime: about 16 times more $\mathrm{P}$ than the applied in the study reported here.

Plant growth, measured as biomass production, was significantly improved by inoculation with any of the five isolates UFSC-Sc68, UFSC-Pt188, UFSC-Ch163, UFSC-Pt132 and UFSC-Pt116. They promoted the production of greater shoot dry matter, compared to treatments inoculated with the other five isolates tested, and to the noninoculated controls (NI $0 \mathrm{P}$ and NI $0.5 \mathrm{P}$ ). Plants inoculated with these five isolates produced as much biomass as the noninoculated controls fertilized with the highest dosage of P (NI 8 P). Isolates UFSC-Sc68, UFSC-Pt188 and UFSC-Ch163 were the most efficient in promoting root production assessed as dry matter. The same efficiency of the isolates is shown in the results of total plant dry matter, with the same five isolates being those most efficient in promoting dry matter accumulation.

Isolates UFSC-Sc68 and UFSC-Ch163 that had facilitated smaller values of $\mathrm{P}$ uptake than the isolate UFSC-Pt188 were able to promote the same amount of plant dry matter as this isolate. This suggests that the effects of ectomycorrhizal fungi on dry matter production may not only be due to a significant increase in nutrient uptake, but could also be due to the increase in water transport or to the production of plant growth promoting substances (Strzelczyk et al., 1997; Di Pietro et al., 2007).

This study has shown that Chondrogaster angustisporus, a new species described by Giachini et al. (2000), from forest plantations in Santa Catarina, 
Brazil, can form mycorrhizas. It has previously been suggested that the members of this genus are mycorrhizal symbionts (Castellano et al., 1989; Hosaka et al., 2006), but this was based only on the occurrence of its fruiting bodies under eucalypt trees.

\section{Conclusions}

1. Chondrogaster angustisporus is a mycorrhizal symbiont of Eucalyptus dunnii.

2. The isolates tested can be classified into three groups according to their efficiency in promoting plant growth: those with high efficiency, isolates UFSC-Sc68, UFSC-Pt188 and UFSC-Ch163; those with moderate efficiency, isolates UFSC-Pt116, UFSC-Pt132, UFSC-Pt22 and UFSC-Pt145; and those with low efficiency, isolates UFSC-Hg93, UFSC-Ch98 and SA9.

3. Inoculation with the isolates UFSC-Sc68, UFSC-Pt188 or UFSC-Ch163 has the potential to significantly reduce the amount of $\mathrm{P}$ fertilization used in E. dunnii nurseries.

\section{Acknowledgements}

To the Universidade Federal de Santa Catarina (UFSC), Florianópolis, SC, Brazil, for facilities; to the Programa de Pós-Graduação em Biotecnologia, UFSC, and Fundação de Auxílio à Pesquisa Científica e Tecnológica do Estado de Santa Catarina (Fapesc), for funding this research; to Professor Márcio J. Rossi, UFSC, for his comments and suggestions; to Dr. Geoff Carr, London, UK, for reviewing the English expression in this manuscript.

\section{References}

ALVAREZ, M.L.; CERCEDA M.C. Chondrogaster angustisporus, nueva cita para Europa. Cryptogamie Mycologie, v.26, p.113-122, 2005.

ALVES, J.R.; SOUZA, O.; PODLECH, P.A.S.; GIACHINI, A.J.; OLIVEIRA, V.L. Efeito de inoculante ectomicorrízico produzido por fermentação semi-sólida sobre o crescimento de Eucalyptus dunnii Maiden. Pesquisa Agropecuária Brasileira, v.36, p.307-313, 2001.

BOGEAT-TRIBOULOT, M.B.; BARTOLI, F.; GARBAYE, J.; MARMEISSE, R.; TAGU, D. Fungal ectomycorrhizal community and drought affect root hydraulic properties and soil adherence to roots of Pinus pinaster seedlings. Plant and Soil, v.267, p.213-223, 2004.

BOUGHER, N.L.; GROVE, T.S.; MALAJCZUK, N. Growth and phosphorus acquisition of karri (Eucalyptus diversicolor F. Muell.) seedlings inoculated with ectomycorrhizal fungi in relation to phosphorus supply. New Phytologist, v.114, p.77-85, 1990.

BRUNDRETT, M.; BOUGHER, N.L.; DELL, B.; GROVE, T.; MALAJCZUK, N. Working with mycorrhizas in forestry and agriculture. Canberra: Australian Centre for International Agriculture Research, 1996. 374p. (Aciar. Monograph, 32).

CASTELLANO, M.A.; TRAPPE, J.M.; MASER, Z.; MASER, C. Key to spores of the genera of hypogeous fungi of North temperate forests, with special reference to animal mycophagy. Eureka: Mad River Press, 1989. 186p.

CHEN, Y.L.; BRUNDRETT, M.C.; DELL, B. Effects of ectomycorrhizas and vesicular-arbuscular mycorrhizas, alone or in competition, on root colonization and growth of Eucalyptus globulus and E. urophylla. New Phytologist, v.146, p.545-556, 2000.

CHEN, Y.L.; KANG, L.H.; DELL, B. Inoculation of Eucalyptus urophylla with spores of Scleroderma in a nursery in South China: comparison of field soil and potting mix. Forest Ecology and Management, v.222, p.439-449, 2006a.

CHEN, Y.L.; KANG, L.H.; MALAJCZUK, N.; DELL, B. Selecting ectomycorrhizal fungi for inoculating plantations in South China: effect of Scleroderma on colonization and growth of exotic Eucalyptus globulus, E urophylla, Pinus elliottii, and P. radiata. Mycorrhiza, v.16, p.251-259, 2006b.

DI PIETRO, M.; CHURIN, J.-L.; GARBAYE, J. Differential ability of ectomycorrhizas to survive drying. Mycorrhiza, v.17, p.547550, 2007.

GARBAYE, J. Utilisation des mycorhizes en sylviculture. In: STRULLU, D.G. (Ed.). Les mycorhizes des arbres et plantes cultivées. Paris: Lavoisier, 1990. p.197-250.

GIACHINI, A.J.; OLIVEIRA, V.L.; CASTELLANO, M.A.; TRAPPE, J.M. Ectomycorrhizal fungi in Eucalyptus and Pinus plantations in southern Brazil. Mycologia, v.92, p.1166-1177, 2000.

GLOWA, K.R.; AROCENA, J.M.; MASSICOTTE, H.B. Extration of potassium and/or magnesium from selected soil minerals by Piloderma. Geomicrobiology Journal, v.20, p.99-111, 2003.

HOFFLAND, E.; KUYPER, T.W.; WALLANDER, H.; PLASSARD, C.; GORBUSHINA, A.; HASELWANDTER, K.; HOLMSTRÖM, S.; LANDEWEERT, R.; LUNDSTRÖM, U.; ROSLING, A.; SEN, R.; SMITS, M.; VAN HESS, P.; VAN BREEMEN, N. The role of fungi in weathering. Frontiers in Ecology and the Environment, v.2, p.258-264, 2004.

HOSAKA, K.; BATES, S.T.; BEEVER, R.E.; CASTELLANO, M.A.; COLGAN, W.; DOMINGUEZ, L.S.; NOUHRA, E.R.; GEML, J.; GIACHINI, A.J.; KENNEY, S.R.; SIMPSON, N.B.; SPATAFORA, J.W.; TRAPPE, J.M. Molecular phylogenetics of the gomphoidphalloid fungi with an establishment of the new subclass Phallomycetidae and two new orders. Mycologia, v.98, p.949-959, 2006.

LANDEWEERT, R.; HOFFLAND, E.; FINLAY, R.D.; KUYPER, T.W.; VAN BREEMEN, N. Linking plants to rocks: ectomycorrhizal fungi mobilize nutrients from minerals. Trends in Ecology and Evolution, v.16, p.248-254, 2001.

MARTIN, F.; DIEZ, J.; DELL, B.; DELARUELlE, C. Phylogeography of the ectomycorrhizal Pisolithus species as inferred 
from nuclear ribosomal DNA ITS sequences. New Phytologist, v.153, p.345-357, 2002.

MARX, D.H. The influence of ectotrophic mycorrhizal fungi on the resistance of pine roots to pathogenic fungi and soil bacteria. I. Antagonism of mycorrhizal fungi to root pathogenic fungi and soil bacteria. Phytopathology, v.59, p.153-163, 1969.

MASON, P.A.; INGLEBY, K.; MUNRO, R.C.; WILSON, J.; IBRAHIM, K. The effect of reduced phosphorus concentration on mycorrhizal development and growth of Eucalyptus globulus Labill. seedlings inoculated with 10 different fungi. Forest Ecology and Management, v.128. p.249-258, 2000.

MUCHA, J.; DAHM, H.; STRZELCZYK, E.; WERNER, A. Synthesis of enzymes connected with mycoparasitism by ectomycorrhizal fungi. Archives of Microbiology, v.185, p.69-77, 2006.

OLIVEIRA, V.L. de; SCHMIDT, V.D.B.; GOMES, N.C.; MAIA, D.C. Spécificité de champignons ectomycorhiziens vis-à-vis d'Eucalyptus viminalis Labill et E. dunnii Maiden. Agronomie, v.14, p.57-62, 1994.

SAWYER, N.A.; CHAMBERS, S.M.; CAIRNEY, J.W.G. Utilisation of inorganic and organic phosphorus sources by isolates of Amanita muscaria and Amanita species native to temperate eastern Australia. Australian Journal of Botany, v.51, p.151-158, 2003.

SMITH, S.E.; READ, D.J. Mycorrhizal symbiosis. London: Academic Press, 1997. 605p.

SOUZA, L.A.B. de; SILVA FILHO, G.N.; OLIVEIRA, V.L. de. Efficiency of ectomycorrhizal fungi on phosporus uptake and eucalypt growth promotion. Pesquisa Agropecuária Brasileira, v.39, p.349-355, 2004.
STRZELCZYK, E.; DAHM, H.; PACHLEWSKI, R.; ROZYCKI, H. Production of indole compounds by the ectomycorrhizal fungus Cantharellus cibarius Fr. Pedobiologia, v.41, p.402-411, 1997.

TEDESCO, M.J.; GIANELLO, C.; BISSANI, C.A.; BOHNEN, H.; VOLKWEISS, S.J. Análise de solo, plantas e outros materiais. 2.ed. Porto Alegre: UFRGS, 1995. 174p.

THOMSON, B.D.; GROVE, T.S.; MALAJCZUK, N.; HARDY, G.E.St.J. The effectiveness of ectomycorrhizal fungi in increasing the growth of Eucalyptus globulus Labill. in relation to root colonisation and hyphal development in soil. New Phytologist, v.126, p.517-524, 1994.

TISDALL, J.M.; SMITH, S.E.; RENGASAMY, P. Aggregation of soil by fungal hyphae. Australian Journal of Soil Research, v.35, p.55-60, 1997.

TURJAMAN, M.; TAMAI, Y.; SEGAH, H.; LIMIN, S.H.; CHA, J.Y.; OSAKI, M.; TAWARAYA, K. Inoculation with the ectomycorrhizal fungi Pisolithus arhizus and Scleroderma sp. improves early growth of Shorea pinanga nursery seedlings. New Forests, v.30, p.67-73, 2005.

WALLANDER, H. Uptake of P from apatite by Pinus sylvestris seedlings colonised by different ectomycorrhizal fungi. Plant and Soil, v.218, p.249-256, 2000.

ZEPPA, S.; SISTI, D.; PIERLEONI, R.; POTENZA, L.; GUESCINI, M.; VALLORANI, L.; STOCCHI, V. Tilia platyphyllos Scop.-Tuber brumale Vittad. vs. T. platyphyllos Scop.- T. borchii Vittad. ectomycorrhizal systems: a comparison of structural and functional traits. Plant Physiology and Biochemistry, v.43, p.709-716, 2005. 